Relations industrielles

Industrial Relations

\title{
High Wages Policy
}

\section{Carl F. Beach}

Volume 25, numéro 3, 1970

URI : https://id.erudit.org/iderudit/028157ar

DOI : https://doi.org/10.7202/028157ar

Aller au sommaire du numéro

\section{Éditeur(s)}

Département des relations industrielles de l'Université Laval

ISSN

0034-379X (imprimé)

1703-8138 (numérique)

Découvrir la revue

Citer cet article

Beach, C. F. (1970). High Wages Policy. Relations industrielles / Industrial

Relations, 25(3), 589-593. https://doi.org/10.7202/028157ar

Tous droits réservés (C Département des relations industrielles de l'Université Laval, 1970
Ce document est protégé par la loi sur le droit d'auteur. L’utilisation des services d'Érudit (y compris la reproduction) est assujettie à sa politique d'utilisation que vous pouvez consulter en ligne.

https://apropos.erudit.org/fr/usagers/politique-dutilisation/ 


\section{COMMENTAIRES}

\section{HIGH WAGES POLICY}

\section{Earl F. Beach}

The refusal by the Canadian Labour Congress and the Canadian National Trades Union to cooperate with the Federal Government's Prices and Incomes Commission is worthy of comment. We intend to develop only one aspect which is very important, yet has not been adequately treated by the very extensive literature on the subject of wage policy for an economy in full or nearly full employment. This is the question of whether wage rates should be increased when the company can afford to do so. Much of the discussion in the literature is about wage increases being forced upon reluctant companies where productivity has not been increasing in proportion, and there has been fairly general agreement that if a company can pay, it should do so. We wish to explore some of the implications of this special question.

\section{THE POSITION OF THE UNIONS}

For many years economists have fairly generally been operating on the assumption that what is good for labour is good for the economy. The rationale for this assumption was based largely, one may suppose, on the fact that labourers comprise such a large part of society, and wage payments such a large proportion of the national income. With agriculture shrinking in relative importance, this becomes more evident.

In an increasingly pluralistic and sophisticated society, however, no group dominates. In 1960, the latest year given in the Historical Statistics of Canada, total union membership in the country was about 1.5 million out of a labour force of about 6.4 million, and a population of some 18 million. The labour force becomes more heterogeneous with increasing numbers of married women taking part. The ranks of those outside the labour force, or only partly in it, are increasing with the numbers of old age pensioners and student who spend more years in school and training. Self employed groups abound. Housewives and other consumer groups are developing distinctive voices.

* See, for example, recent studies of the Economic Council of Canada, especially Bodkin, R.G., Bond, E.P., Reuber, G.L., and RoBINSON, T.R., Price Stability and High Employment, Special Study \# 5 (EC 22-2/5). 
Numbers alone are, however, not the whole answer. Unions are firmly entrenched in large, strategic, dynamic industries, such as steel, automobiles, and mining industries. They are in a position to speak with some impact.

Thus, when the officials of the central union groups announced that they would not cooperate with the Federal Government's policy on prices and incomes, and hence refuse to share the responsibilities for the nation's current economic difficulties, it is time to examine the matter and spell out some of the important economic relations involved which have not been given the importance due to them.

\section{HIGH WAGES AND POVERTY}

Labour unions have long been associating themselves with the cause of poverty. But this connection is becoming increasingly tenuous. Not only do the high incomes of the electricians and the plumbers put them in an altogether world from the poverty income groups ${ }^{1}$, but the high wage policy of the stronger unions is emphasizing the pinch of poverty for the marginal workers.

Within the plant there are no longer any soft jobs for weaker workers. Marginal workers are weeded out. Selection and training are done with more care, to assure that workers are worth the high wage.

Industries are changing their form and location in response to changing technology, the pace of which is heightened by the continuous rise in wage rates. Most companies want to pay higher wages if they can. They may argue that it increases consumer income, if they are a large enough element in the economy, such as a large automobile manufacturing company. They may wish to have the prestige and a better selection of workers which comes from a high wage policy. Management will also find it easier to raise their own salaries if top wage rates creap up towards theirs.

When a company feels that it can live with a high wage rate, and adopts a technology that allows it, this results in older plants becoming obsolete and some older workers, too. Ben Seligman decries the obsolescence of a western Pennsylvania steel plant by the building of a large new one on the eastern coast. This is the counterpart of the steel workers' demand that technology keep up so that high wages can be paid.

Similarly, the tragedy of South Bend, Indiana, which also figures prominently in Seligman's outrage ${ }^{2}$, is the counterpart of rapidly rising wages in the automobile industry. Marginal companies are forced out of the competition.

In the plant, marginal workers disappear. In the company, marginal plants are closed. In the industry, marginal companies are forced out. In

1 Emphasized when unions practice exclusion of racial and immigrant groups.

2 Seligman, Ben, Most Notorious Victory, Collier Macmillan, 1966. 
the economy, marginal industries have difficulties. Of course, the higher incomes create greater spending by those who enjoy them. There need not be a fear of general depression. But the obsolescence of men and machines means poverty for the unfortunate and rapid adjustment for those who wish to escape it.

It is fairly generally agreed that the economy should improve its efficiency by weeding out marginal workers, marginal plants, and marginal companies, and with less certainty, marginal industries. But when the speed of adjustment is rapid, relative to the ability of people to adjust, society must be prepared to assist. High wages for everybody is not the answer; the worker must earn his pay. Sub-marginal workers must be given other kinds of assistance such as re-training, re-location, family benefits, and early retirement benefits. It is not generally the fault of the unfortunates and certainly not theirs alone. Chance changes in the economy are important.

The economy, in advancing its efficiency of production, can afford to help those whom it has discarded. The successful ones have stepped on the shoulders of the less successful ones, and should help them. Thus, business unionism should be seen in terms of the realities of the present, and not confused with sentiments of the past.

\section{High WAGES AND PRODUCTIVITY}

Claims for high wages are supported by studies of productivity giving ratios of the output per unit of labour input. The implication is that the productivity of the labour increases. But when a man works no harder, and for the same number of hours, even if he is somewhat better trained, and has had more experience, it is hard to accept the implication that it is * their > product, that all of this increase should go to them, or even that a substantial proportions of it.

Statisticians have pointed out that there are very serious problems of measurement in such ratios ${ }^{3}$, and furthermore, even if the ratio doubles, that does not mean that wage rates may be doubled ${ }^{4}$. Only a full accounting of all costs could tell us what we need to know.

With the help of such statistics, the argument is often made that when a company can par, it should do so. Sometimes the argument is pushed so far as to imply that nothing need to be paid out to capital, that all dividend payments should go to wages. Sometimes only the increase in profits is considered legitimately the claim of wage earners. In the latter case, the choice of a base for measuring the increases is very important.

3 Kendrick, John W., Productivity Trends in the United States, National Bureau of Economic Research, 1961.

4 BEACH, E.F., «Wage Comparisons and Productivity》 Relations Industrielles - Industrial Relations, P.U.L., vol. 24, no 1, Québec, Jan. 1969, p. 198. 
The former argument is patently absurd, and the second may or may not be, depending upon all the factors. If an industry starves its return to capital, wage earners will eventually starve, as well. This matter has been argued at such length that it need not be followed further here.

Suppose now, that good dividends have been paid, and even the additions to capital that brough about the increase in productivity has been and is being adequately remunerated. If there are extra profits, do the labourers have any claim that is superior to that of the customers, or of others. It would seem to be fair that all share in some way, but it would take a bold man to say what the shares would be.

Professor J.K. Galbraith expresses 5 a commonly held idea that the extra costs is passed on to the consumers with a rise in prices. This is said to be particularly characteristic of strong industries, with strong unions.

This is much too simple a view ${ }^{6}$. It is the job of the management to make calculations of things like elasticities of demand for the product 7 . They also calculate the costs and results of technological change that will reduce direct labour, and when costs can be frozen in the form of: machinery and other real capital, this is a way of escaping from some of the pressure of constantly increasing wage rates. The result may be a transformation of the industry, as in the case of cement ${ }^{8}$, a change in its locale, as in textiles and tobacco manufacturing, or a change in its nature, as in construction and in retailing. In none of these cases are the causal factors simple, but also, in none of them is the matter of direct wage cost absent. It can be extremely important.

The transformation of the industry as the result of rapidly increasing wage rates may be illustrated by the bituminous coal industry in the United States. Mechanization of the mines was essential to bring about the change. For those miners who continued to work, the wages and the pensions were good ; but there were many depressed areas in the Appalachian hills as a result.

\section{Higli WAGES AND INFLATION}

It is possible, therefore, that wage rates can be increased too fast in the sense that it forces too rapid a change in technology for the economy in general, and for labourers in particular. It may be that the rate of increase is too fast for an altogether different reason. If, as is suggested else-

5 The New Industrial State, Houghton Mifflin, Boston, 1967.

6 Morton, W.A., «Trade Unionism, Full Employment and Inflation》, American Economic Review, March 1950, pp. 13-39.

7 Galbraith feels that the strong industries manipulate demand, so that these elasticities are unimportant, op. cit.

8 Harwell, R. Sterling, «For the Cement Industry: A Time of Crisis》, Rock Products, April 1968, and May 1968. 
where, increased mechanization can be inflationary, then the pressure for high wages in an attempt to outpace inflation of consumer prices may help to intensify the inflationary process itself and make the control of inflation even harder. There is some evidence of this kind of pressure in the present situation, and resulting difficulties of control because of the pressures to counter wage costs by mechanizing further, putting further pressures on demands for capital.

It is natural for any group to seek shelter from difficulties, but if their seeking makes life harder for others, it is less easy to justify the change. Such can be the case even when companies can pay wages increases asked. Indeed, if unions press hard enough, they will force loss of jobs for their members, as in the case of the bituminous coal miners, and they will in current circumstances of inflation hard enough, they will force loss of jobs for their members, as in the case of the bituminous coal miners, and they will in current circumstances of inflation lessen their own chances of winning the race with consumer prices. The world will not hold still for them - they are an essential element in it.

\section{A SUGGeSTION}

The Prices and Incomes Commission might make a very detailed study of wage rate increases that have been agreed to in all collective bargaining agreements for some time past. The study might include increases for one, two, or three years. A frequency distribution might be drawn up to see how often certain increases were agreed to, i.e., the number of ten per cent increases, the number of nine per cent increases, etc. A careful study could be made of the highest increases, and of the effects upon the industry, its prices, employment, organizations, etc. In this way, some idea of the effects of these increases could be obtained. There are probably no clearcut answers, but the data should be helpful in setting an upper limit to increases in the future, such that all increase above that limit must be subjected to the scrutiny of the Commission or other designated body.

Such a ceiling would not be absolute, but it should slow up the process of granting high increases. The unions would fight such a rule very strenuously, but it becomes increasingly likely that with a little more inflation experience over the next year or two that the public may be ready to over rule them. The rule might be broadened, of course, to apply to price increases as well - that is to all increases of more than - say - ten per cent within any twelve month period. Some such arrangement is far superior to a freeze or an examination of all increases by some governmental organization. 